\title{
Implementing ERCoRe in Learning: Will Metacognitive Skills Correlate to Cognitive Learning Result?
}

\author{
Nur Ismirawati ${ }^{1, *}$, Alyosius Duran Corebima ${ }^{2}$, Siti Zubaidah $^{2}$, Rizhal Hendi Ristanto $^{3}$, \\ Andi Nuddin ${ }^{4}$ \\ ${ }^{1}$ Department of Biology Education, Universitas Muhammadiyah Parepare, Indonesia \\ ${ }^{2}$ Department of Biology Education, Universitas Negeri Malang, Indonesia \\ ${ }^{3}$ Department of Biology Education, Universitas Negeri Jakarta, Indonesia \\ ${ }^{4}$ Faculty of Pertanian, Peternakan, dan Perikanan, Universitas Muhammadiyah Parepare, Indonesia
}

Received September 8, 2019; Revised January 27, 2020; Accepted March 24, 2020

Copyright $\bigcirc 2020$ by authors, all rights reserved. Authors agree that this article remains permanently open access under the terms of the Creative Commons Attribution License 4.0 International License.

\begin{abstract}
The level of the students' cognitive learning results is influenced by their ability in managing and evaluating their learning activities, known as metacognitive skill ability. This investigation was a correlational investigation designed at investigating the connection among metacognitive skills. However, the study linked to the connection among the 2 variables by the implementation of ERCoRe model has not been conducted yet, because ERCoRe learning model is included as a new learning model. This remained quasi-experimental by means of pretest and posttest nonequivalent switch project of $2 \times 2$. This research was analyzed by Regression. The samples of this research consisted of 66 pupils of Senior High School in Pangkep District, Indonesia. The results of this research find that the ERCoRe learning model has a very strong contribution (85.6\%) and the linear regression equation is $\mathrm{Y}=0.880 \mathrm{X}+13.11$ related to the connection among metacognitive skills and cognitive knowledge results of Senior High School. Therefore, this model can be used as a reference for teachers to improve their students' cognitive learning results.
\end{abstract}

Keywords Cognitive Learning Results, ERCoRe learning, Metacognitive Skills

\section{Introduction}

Metacognition is first introduced by John Flavel in 1970. He described metacognition as cognition about cognitive phenomena or better known as thinking about thinking [1]. Dwoning [2] also revealed that metacognition was thinking about thinking, or the second level of cognition related to is the ability of self-reflection of the ongoing cognitive processes and played an important role in human awareness. Metacognition is described as an act of self-monitoring and self-regulation [3]. Metacognition refers to the deliberate use of cognitive strategies to control cognition $[4,5]$.

Desoete [6] stated that metacognition had three apparatuses on problem-solving, including metacognition knowledge, metacognition skills, and metacognition belief. Metacognition knowledge is related to a person's declarative data, procedural data, and conditional data in problem-solving [7]. Metacognitive skills are associated to estimate skills, preparation skills, monitoring skills, and assessment skills [8], while metacognitive reliance is related to self-concept, self-efficacy, motivation, and the concept of knowledge and learning [9].

Metacognitive skills have a contribution to learning success [10] [11]. Metacognitive skills can help to progress pupils' thoughtful services which in chance affects their results. Developing students' metacognitive services is a treasured goal because these skills benefit students in developed self-regulated pupils. Self-regulated will be accountable for their personal learning improvement and adapt their learning plans to realize the demands of the mission [12]. Self-regulated learners will become independent learners who can improve their cognitive learning results because they can control their learning process.

Metacognitive skill is an independent variable to improve cognitive learning results [13]. The result of cognitive learning has a significant correlation with the students' metacognitive skills. Fouche \& Lamport [14] 
stated that metacognitive activities could improve students' learning results. The research conducted that the students consistently taught by using metacognitive skills had a higher score on tests and showed significant improvement in cognitive processes than those who were not taught by using metacognitive skills. Metacognitive skills have a positive connection with students' learning achievement [16]. The pupils who have respectable metacognitive skills will also have good cognitive learning results [17] [18].

Metacognitive skills play a significant role in many types of activities, for example, questioning to selves, self-control [19], reasoning, problem-solving, attention, and memory $[20,21]$. The use of metacognition is related to the process of improving efficiency in learning activities, such as a student regulating his learning habits with variations, including how to organize his study time, determining with whom he studies, and monitoring his own learning success or with the help of others. These processes can indirectly improve students' cognitive learning results.

Metacognitive skills are necessary for positive learning. This enables students to be bright to achieve their cognitive skills and to be aware of their faintness so that they can improve their further actions. According to Rahman, et al [16], metacognitive skills enable students to make planning, follow developments, and monitor the learning process. In this case, the role of the teacher is very important in helping students to improve their metacognitive skills. The students who use their metacognitive skills have better performance than those who do not use their metacognitive skills.

Metacognitive skills can be applied in the classroom learning procedure, finishing the implementation of a learning model that has the potential to empower metacognitive skills. It can be trained through constructivist learning. According to Peters [22], there is a strong association among metacognitive skills and constructivist learning activities. Constructivist learning can improve metacognitive skills because constructivist learning requires students to construct their own knowledge [15]. The activity to construct their own learning makes the students aware of the position of their cognition when they construct their knowledge. As a result, their metacognitive skills will be trained through self-reflection, re-plan, review, and re-evaluating their learning results [23].

There are many researchers who report that certain learning models based on metacognitive skills will have an encouraging correlation with students' cognitive learning. [24-28]. The fact that metacognitive skills enable the pupils to apply this process is an additional consideration in determining the learning objectives to organize, evaluate and manage the learning effectively in order to achieve high academic achievement [29].

One of the cooperative and constructivist learning models is the ERCoRe learning model. The characteristics of ERCoRE learning model are: it increases pupils' metacognitive skills, encourages the students to become independent learners, and encourages the students to always construct knowledge through cooperative activities [30][31]; the steps of ERCoRe learning model consist of (1) Eliciting by assigning tasks to students to discover important concepts of reading passages through reading; (2) Restructuring by directing the students to collaborate with group members in constructing their knowledge in the form of mind mapping; (3) Confirming which invites the students to present their knowledge in order to gain new information through discussions between groups; (4) Reflecting, inviting the students to rearrange their knowledge through mind mapping which is carried out individually.

Research that uses the ERCoRe learning model by looking at metacognitive skills and cognitive learning outcomes does not yet exist. However, several research results have proven that there is a correlation between metacognitive skills and cognitive learning outcomes through the application of different learning models. The results showed that there was a strong correlation among these variables at the implementation of a learning model.

The results of research conducted by [32] [33] show a strong correlation between metacognitive skills and cognitive learning outcomes. This is due to the fact that metacognitive skills enable students to plan, monitor the learning process, and reflect on the learning outcomes that have been obtained.

This study examines the correlation between metacognitive skills and cognitive learning outcomes of middle school students who are trained using the ERCoRe learning model.

\section{Materials and Methods}

The method used in this research is correlational, which is designed to explore the correlation between metacognitive skills and cognitive learning outcomes on the application of the ERCoRe learning model in Biology Learning in High Schools in Pangkep Regency, Indonesia. This research was conducted for six months in the even semester in 2016.

The population in this study was 88 students. The class samples were selected using a random sampling technique. The Sample selection conducted in this experimentation has two-stage, school certain and class conclusive. İn Substance, school choice found with the group the Student' National Examination average in 9 state senior high school in Pangkep. The Evidence was then evaluated using Anova and pursued by Least Significant Difference test for classifying school toward high academic achievers and low academics. Formerly, 1 school from any group categories for more sampling process. 
The secondary phase was appointing the experimental and control class from the pair high academic achiever and low academic achiever schools over the employment test, in order to obtain a total sample of 66 students. The conclusion of the employment test follows the selection of two homologous classes. The degree was aimlessly preferred as the experimental and control class. The instrument used to measure the metacognitive skills was an essay test integrated with a cognitive learning result test with the total number of the test items as many as 10 items. Before being used, the instrument was tried out to 40 students of class XII to control the validity and reliability of the instrument. The research instrument was administered before and after learning. The data of metacognitive skills as well as of cognitive learning result were obtained by using rubrics. The rubric of cognitive learning results was adapted from [34] with a scale of $0-4$, and the rubric of metacognitive skills was developed by Corebima [35] with a scale of 0-7. The Information was analyzed using simple linear regression analysis to find out the correlation between metacognitive skills and cognitive learning outcomes.

The instruments in this study include the syllabus, lesson plans, and student worksheets that were previously validated by two validators before use. Valid for syllabus 94.16, for essay and test for lesson plan 97.39, and for worksheet 96.47. Validity learning outcomes integration with metacognitive skills from 15 essay test items were found to be valid. The test here was developed by referring to the Cognitive 3 to Cognitive 6 levels of Bloom's taxonomy. Furthermore, the data were analyzed using the Pearson Correlation Test. The reliability of the assessment (Essay test) was also done to establish that the interview frequently reverses the Consistent variables. The reliability was measured using Cronbach's Alpha, constitutional flexibility coefficient was 0.753 .

\section{Results}

The research results of the correlation between metacognitive skills and cognitive learning results by using ERCoRe learning model are presented in Table 2. Table 2 shows the correlation analysis with a significance level of 0.000 which means that the correlation among metacognitive skills and cognitive learning results is very strong, with the contribution of $85.6 \%$ and the linear regression equation is $\mathrm{Y}=0.880 \mathrm{X}+13.11$.

Table 1. Summary of ANOVA Test of the Correlation between Metacognitive Skills and Cognitive Learning of Senior High School Students taught by using ERCoRe learning model.

\begin{tabular}{|c|c|c|c|c|c|}
\hline Model & Sum of Squares & Df & Mean Square & F & 184.077 \\
& & & 3408.509 & $000 \mathrm{~b}$ \\
Regression & 3408.509 & 1 & 18.517 & \\
Residual & 574.019 & 31 & & \\
Total & 3982.528 & 32 & & \\
\hline
\end{tabular}

(Source: personal document)

Table 2. Summary of Regression Correlation between metacognitive Skills and Students' cognitive Learning Results

\begin{tabular}{|c|c|c|c|c|}
\hline Model & $\mathrm{R}$ & R Square & Adjusted R Square & Std. Error of the Estimate \\
\hline 1 & $.925 \mathrm{a}$ & .856 & .851 & 4.30311 \\
\hline
\end{tabular}

(Source: personal document) 


\section{Discussion}

Results of this research confirmed that there is a positive correlation between metacognitive skills and cognitive learning results in the implementation of ERCoRe learning model. This suggests that the increase in metacognitive skills will be followed by an increase in the students' cognitive learning results. This research is in line with the research result of Kristiani, (2009); Singh, (2012); Bogdanovic et al, (2015) [36-38] who reported that metacognitive skills had a positive and significant correlation with learning results in science learning.

A strong correlation between metacognitive skills and cognitive learning results is due to the implementation of learning models. According to Corebima (2010), the empowerment of metacognitive skills in learning can be done completely through the habituation of cognitive learning strategies, as well as through the implementation of appropriate learning strategies. The research results by Sumarno [40] Rahman \& Phillips [41] and Palennari [3] have revealed that there was a correlation between metacognitive skills and cognitive learning results because of the implementation of learning models. The higher the students 'metacognitive skills are, the higher their learning results will be. Conversely, the lower the students' metacognitive skills are, the lower their learning results will be.

Correlation between metacognitive skills and cognitive learning results is proven to be positive; training metacognitive skills can make the students aware of learning, planning their learning, controlling their learning process, and evaluating their ability as learners, and reflecting on their learning, including assessing their weaknesses and strengths. The results of this research are consistent with Camahalan \& Faye [42] who reported that there was a significant positive correlation between academic accomplishment and the use of self regulation strategies, beliefs, and intuition regarding the ideas to solve problems and how the ideas resolved problems [43]. In addition, it appears that metacognitive skills help students improve their motivation in learning [44].

The results of research conducted by Bogdanovic, et al [38] show that there is a correlation between metacognitive skills and academic abilities; the advantages of metacognitive skills include helping students become students who are responsible for their achievements, adjusting their learning strategies so as to achieve the desired learning goals. Arezlvarez [45] suggested that metacognition plays an important role in learning achievement.

The contribution of metacognitive skills toward cognitive learning of class XI senior high school students who were taught biology lessons by using ERCoRe learning model was as much as $85.6 \%$. The use of metacognition is related to the process of efficiency in improving learning activities, such as a student regulating his learning habits with variations, including how to organize his study time, determining with whom he studies, and monitoring his learning success by himself or with the help of others. These processes can indirectly improve the students' cognitive learning results. Fouche \& Lamport [14] stated that metacognitive activities would improve students' learning.

Metacognitive skills correlate positively to cognitive learning outcomes. The results showed students who have metacognitive skills that develop will show a positive relationship with cognitive learning outcomes [46]. According to Veenman et al, [10], someone who develops metacognitive skills has a positive contribution to the learning process [9]. These results indicate that the development of metacognitive skills can cause an increase in learning outcomes. As such, metacognition is an important component of intelligence and cognition and has a significant influence on academic success.

This significant contribution is caused by the fact that the students' metacognitive skills are gradually empowered at every syntax of ERCoRe learning model. For example, at the first stage of the syntax of ERCoRe learning model Eliciting, the activities are reading the learning material to be learned in the classroom. According to Chellamani [46], by reading, the students' metacognitive skills can be empowered because they understand explicitly and implicitly about the demands of the task, identify the important aspects of a message, focus on the main content, concentrate on the ongoing activities to determine whether what understood is correct or not, ask himself if the goal is already accomplished, and take corrective action if there is a misunderstanding. Ahmadi, Ismail, \& Abdullah [47] stated that metacognitive strategies could provide opportunities for students to do planning before reading, control the process of reading, and evaluate themselves.

The second stage is Restructuring. This is an activity in which the students construct their own knowledge after reading through mind-mapping activity. The use of mind mapping is a part of metacognition [48]. According to Tanriseven [49], the use of mind mapping in learning can develop student's self-regulated learning skills. Buzan [50]; Şen \& Çoban, [51] added that mind mapping helped the students to remember information more easily than using traditional noting techniques. Various studies have revealed many positive effects of mind mapping in the teaching and learning process, one of which is to improve students' metacognitive skills [52].

The third stage is confirming, as an activity in which the students confirm their knowledge through group discussions. Discussions among students enable them to find answers to the problems together. Each student has the opportunity to monitor and evaluate the results of their thought and the thoughts of the other students as partners. The process of comparing cognitive activities also indicates that the students' metacognitive skills are well 
empowered [53]. The students who learn in small groups have a tendency to train their metacognitive skills better than those who learn by listening to a lecture from the teacher.

The last stage of this learning model is reflecting. The reflecting activity is done by recreating a mind map independently. The reason for remaking the mind map is to know the changes in the students' knowledge after experiencing the previous stages and to reinforce the knowledge gained. The mind map allows students to create visual images to improve their learning [54], and it can be used as metacognitive tools that enable them to make a connection with the learning material in a meaningful way [55] The Mind mapping stage makes the teacher play a role in guiding the students to experience learning that enables them to discover principles and construct their understanding independently [56] [57].

When compared to other learning models like GI, TTW, and TPS, the percentage of the relative contribution of ERCoRe learning model is $85.6 \%$ higher than that of the Group Investigation integrated with Think Talk Write learning model with the percentage of the relative contribution as much as 7,77\% [58] and that of the TPS learning model with the relative contribution as much as $80,9 \%$ [59].

It can be proven that although the ERCoRe learning model is a relatively new learning model, it has contributed the same or even higher than other learning models. The students' metacognitive skills should not be developed by itself, but it should be prepared well, and the students should be made accustomed to a learning environment which requires them to implement metacognitive skills [60] [61]. Such a learning environment provides the opportunity for pupils to practice self-directed that reassures them to be self-controlled and allows them to discover more facts about topics such as being forced to read a particular topic so that they get a better awareness of dissimilar issues. With the learning process, the pupils are trained to learn independently, to do research by themselves, to filter irrelevant information and to focus on more significant things, teamwork, problem-solving, and learn how to apply concepts of a problem. It supports pupils to engage in additional information and makes them responsible for their learning. Metacognitive skills can be skilled to the pupils to improve their learning because constructing knowledge requires not only cognitive elements but also the metacognitive element [25]

According to Corebima [62], learning in Senior High Schools and Universities should be based on learning models. In this case, as a facilitator, the teacher should select and implement a variety of innovative learning models. Several vital phases to explain metacognitive skills are as: (a) explain the pupils that learning is not incomplete in amount, and the individual's ability in learning can be modified, (b) teach the students how to usual learning areas and plan for their achievement, and (c) provide the pupils with many occasions to preparation monitoring their learning actions. Instill the students that these things are important as well as are for the students themselves [62].

The students' learning results can be said to be qualified if the students are able to consciously control their cognitive processes continually, which consequently improves their metacognitive skills. Overall the outcomes of this research found that there is a significant correlation between metacognitive skills and cognitive learning results of class XI Senior High School students in Pangkep District at the implementation of ERCoRe learning model.

\section{Conclusion}

Grounded happening the results and discussion of this research, it can be determined that at the implementation of ERCoRe learning model, there is a significant correlation between metacognitive skills and cognitive learning results, with the influence of $85.6 \%$ and the linear regression equation is $\mathrm{Y}=0.880 \mathrm{X}+13.11$.

\section{Suggestions}

The results of this research provide information to educators that to improve students' cognitive learning results continuously requires empowering the students' metacognitive skills through cooperative learning models based on a constructivist approach, and one of which is the ERCoRe learning model.

\section{REFERENCES}

[1] Lai. R.E. Metacognition: A Literature Review, Pearson, 2011.

[2] Downing, K.J. Self-efficacy and Metacognitive Development, The International Journal of Learning, Vol. 16, No. 4, 185-199, 2009.

[3] Palennari, M. Exploring the Correlation Between Metacognition and Cognitive Retention of Students Using Some Biology Teachings, Journal of Baltic Science Education, Vol. 25, No. 5, 617-629, 2016.

[4] Efklides A. Metacognition: Defining its facets and levels of functioning in relation to self-regulation and co-regulation, European Psychologist, Vol. 1, No. 4, 277-287 (2008).

[5] Baş, F., \& Sağırlı, M. O. A Content Analysis of the Articles on Metacognition in Education in Turkey, Education and Science, Vol 42, No. 192, 1-33, 2017.

[6] Desoete, A. Off-line metacognition in children with mathematics learning disabilities (unpublished dissertation). Faculty of Psychology and Educational Sciences of the Ghent University, Belgium, 2001. 
[7] Veenman, M.V.J. Metacognition and Learning: Conceptual and Methodological Considerations, Business Media, 2006.

[8] Moore, K. C. Constructivism \& metacognition. Retrieved from http://www.tier1.performance.com /Articles/constructivism.pdf, 2004.

[9] Erdoğan, F., \& Şengül, S. The Effect of Cooperative Learning Method Enhanced with Metacognitive Strategies on Students' Metacognitive Skills in Math Course, Education and Science. Vol. 42, No. 192, 263-301, 2017.

[10] Veenman, M.V.J., Wilhelem, P., \& Beishuizen, J. J. The relation between intellectual and metacognitive skills from a developmental perspective, Learning and Instruction, Vol. 14, 89-109, 2004.

[11] Veenman, M.V.J. Assessing Developmental Differences in Metacognitive Skills with Computer Logfiles: Gender by Age Interactions, Psychological Topics, Vol. 23, No. 1, 99-113, 2014.

[12] Eggen, P.D \& Kauchak, P.P. Strategies for Teacher: Teaching Content and Thinking Skill. Boston: Allyn \& Bacon, 1996.

[13] Dunning, D., Johnson, K., Ehrlinger, J., \& Kruger, J. Why People Fail to Recognize Their Own Incompetence, Current Directions in Psychological Science, Vol. 12, No. 3, 2003.

[14] Fouche, J., \& Lamport, M.A. Do Metacognitive Strategies Improve Student Achievement in Secondary Science Classrooms, Christian Perspectives in Education, Vol. 4, No. 2, 1-25, 2011.

[15] Ismirawati. N., Corebima. D. A., Zubaidah. S., \& Syamsuri. I. ERCoRe Learning Model Potential for Enhancing Student Retention among Different Academic Ability, Eurasian Journal of Educational Research, Vol. 77, 19-34, 2018.

[16] Rahman, S., Yasin, M. R., Arifin, R.S., Hayati, N., \& Yosoff, N. Metacognitive skills and the development of metacognition in the classroom. 9th WSEAS International Conference on Education and Educational Technology (EDU '10). Iwate Prefectural University, Japan October 4-6, 2010.

[17] Wicaksono, C, G, A., \& Corebima, A, D. The Relationship Between Students' Metacognitive and Retention Skills in Reciprocal Teaching Learning and High School Jigsaw in Malang, Bioma, Vol. 4, No.1, 2005.

[18] Antika, L. T. Hubungan Antara Minat Baca, Keterampilan Metakognitif, dan Keterampilan Berpikir Kritis dengan Hasil Belajar Biologi Berbasis Reading Concept Map Think Pair Share (TPS) [The Correlation between Reading Interest, metacognitive Skills and critical Thinking Skills toward Biology Learning Results based on Reading Concept Map at Think Pair Share (TPS)]. Unpublished Thesis, Malang: Pascasarjana Universitas Negeri Malang. 2015.

[19] Safari, Y., \& Meskini, H. The Effect of Metacognitive Instruction on Problem Solving Skills in Iranian Students of Health Sciences, Glob J Health Sci, Vol. 8, No. 1,150-156, 2016.

[20] Dignath, C., Büttner, G., \& Langfeld, H.-P. How can primary school students learn self-regulated learning strategies most eff ectively? A meta-analysis on selfregulation training programmes. Educational Research Review, Vol. 3, No. 2, 2008.

[21] Dignath, C., \& Büttner, G. Components of fostering self-regulated learning among students. A meta-analysis on intervention studies at primary and secondary school level. Metacognition and Learning, Vol. 3, No. 3, 2008.

[22] Peters, E. Connecting inquiry to the Natire of Science as a Metacognitive Resource, Scinece Education, 2006.

[23] Djamahar, R., Ristanto, R. H., Sartono, N., Ichsan, I. Z., Darmawan, E., \& Muhlisin.A. Empowering Student's Metacognitive Skill Through Cirsa Learning, The 2nd Annual International Conference on Mathematics and Science Education IOP Conf. Series: Journal of Physics: Conf. Series 1227, 2019.

[24] Javanmard, A. Investigating the Relationship between Self-Efficacy, Cognitive and Metacognitive Strategies, and Academic Self-Handicapping with Academic Achievement in Male High School Students in the Tribes of Fars Province, Journal Life Sci. Biomedicine, Vol. 3, No. 1, 27-34, 2012.

[25] Candrasari, A., \& Soegiarto, B. Korelasi Antara Keterampilan Metakognisi Dengan Hasil Belajar Hidrolisis Garam Menggunakan Model Pembelajaran Kooperatif Tipe Think-Pair-Share Di Man Mojosari [The Correlation between Metacognition Skills and Salt Hydrolysis Learning Results using Cooperative Learning Model of Think-Pair-Share in MAN Mojosari], Unesa Journal of Chemical Education, Vol. 3, No. 3, 232-238, 2014.

[26] Bahri, A. \& Corebima, D. A. The Contribution of Learning Motivation and metacognitive Skill on Cognitive Learning Outcome of Students Within Different Learning Strategies, Journal of Baltic Science Education, Vol. 14, No. 4, 487-500, 2015.

[27] Kritstiani, N.,Susilo, H., Rohman, F.,\& Corebima, A. D. The contribution of students' metacognitive skills and scientific attitude towards their academic achievements in biology learning implementing Thinking Empowerment by Questioning (TEQ) learning integrated with inquiry learning (TEQI), International Journal of Educational Policy Research and Review, Vol. 2, No. 9, 113-120, 2015.

[28] Ratri, C.T.V., \& Sugiarto, B. The Correlation between metacognitive Skills and Learning Results of Class XI Students using Direct Instruction Model on Hydrolysis Learning Material. Unesa Journal of Chemical Education, Vol. 5, No. 2, 104-110, 2016.

[29] Cera, R., Mancini, M., \& Antonietti, A. Relationship between Metacognition, Self-efficacy and Self-Regulation in Learning, Journal of Education Cultural and Psychological Studies, Vol. 7, 2013.

[30] Ismirawati. N., Corebima. D. A., Zubaidah. S., \& Syamsuri. I. Prototype of ERCoRe Learning Model to improve metacognitive skills, Proceedings of National Conference on Science Education Master in Science Education and Doctor Education Science. FKIP UNS, 2015.

[31] Zubaidah, S., Mahanal, S., Rosyida, F., kurniawati, Z, L., Sholihah, M., \& Ismirawati, N. Using Remap-TmPS Learning to Improve Low-Ability Students' Critical Thinking Skill, Asia-Pacific Forum on Science Learning and Teaching, Vol. 19, Issue 1. 2018. 
[32] Siswati, B. H., \& Corebima, A.D. Study on the Correlation between metacognitive Skills and Concept gaining of Biology at several Learning Models. Asia-Pacific Forum on Science Learning and Teaching, Vol. 18, No. 1, 2017.

[33] Siswati, B. H., \& Corebima, A.D. The Correlation between metacognitive Skills and cognitive Learning Results of Science and Biology of Junior and Senior High School Students at The Implementation of Think Pair Share (TPS) Learning Strategy. Proceeding of Seminar Nasional Biology 378-384, 2016.

[34] Oyuga, A. P., Aloka, O. J. P., \& Raburu, P. Relationship between Meta-Cognitive Learning Skills and Academic Performance among Orphaned Secondary School Students of Kenya, International Journal of Advanced and Multidisciplinary Social Science, Vol. 2, No. 2, 40-46, 2016.

[35] Hart. D. Authentic Assessment A Hand Book for Eduators. California. Addision-Wesley Publisih Company, New York, 1994.

[36] Kristiani, N. The Effect of Learning Strategies and Academic Ability and it's Interaction on metacognitive Skills and cognitive Learning Results of Class X Senior High School 9 Malang, Unpublished Thesis, Program Pascasarjana Universitas Negeri Malang, Malang, 2009.

[37] Singh, Y.G. Metacognitive Ability of Secondary Students and Its Association with Academic Achievement in Science Subject, International Indexed \& Referred Research Journal, Vol. 4, No. 39, 2012.

[38] Bogdanović, I., Bogdanović, Z. D., Cvjetićanin,S., Segedinac, M., \& Budić, S. Students' Metacognitive Awareness and Physics Learning Efficiency and Correlation between Them, European $\mathrm{J}$ of Physics Education, Vol. 6, No. 2, 18-30, 2015.

[39] Corebima, A.D. Empower Skills during Science Learning for Our Future, Paper presented at the National Seminar on Science, Universitas Negeri Surabaya, 2010.

[40] Sumarno, J. Improving Mathematics Concept Gaining through Metacognitive Learning Strategy, Widyatama, Vol. 4, No. 4, 2007.

[41] Rahman, S., \& Phillips, J.A. The Correlation between metacognitive Awareness, Motivation and academic Achievement of Univeristy Students, Jurnal Pendidikan, Vol. 31, 21-39, 2006.

[42] Camahalan, F.M.G. Effects of Self-Regulated Learning on Mathematics Achievement of Selected Southeast Asian Children, Journal of Instructional Psychology, Vol. 33, No. 3,2000 .

[43] Schoenfeld, A. H. Learning to Think Mathematically: Problem Solving, Metacognition, and Sense-Making In Mathematics, Handbook for Research on Mathematics Teaching and Learning (D. Grouws, Ed.), MacMillan, New York, 1992.

[44] Hrbápková, K., Hladík, J., Vávrová, S. The Relationship Between Locus of Control, Metacognition, and Academic Success. International Conference on Education and Educational Psychology (ICEEPSY 2012). 1805 - 1811, 2012.
[45] Álvarez, A. O. Reflecting on metacognitive strategies in FL teaching and learning, Cuadernos de Lingüística Hispánica, 16, 69-82. 2010.

[46] Rivers. P. W. Autonomy at All Costs: An Ethnography of Metacognitive Self-Assessment and Self-Management among Experienced Language Learners, The Moderen Language Journal. Vol. 85, No. 2, 2001.

[47] Ahmadi, R. A., Ismail, H. N., \& Abdullah, M. K. The relationship between students' reading motivation and reading comprehension, Journal of Education and Practice, Vol. 4, No.18, 8-17, 2013.

[48] Willingham, D. T. Critical thinking: Why is it so hard to teach? American Educator, Vol. 31, 8-19, 2007.

[49] Tanriseven, I. A Tool That Can Be Effective in the Self-regulated Learning of Pre-service Teachers: The Mind Map, Australian Journal of Teacher Education, Vol. 39, No $1,2014$.

[50] Buzan, T. Smart Book of Mind Mapp, PT. Gramedia Pustaka Utama, Jakarta, 2009.

[51] Şen, E., \& Çoban, S. The Effect of Using Mind Mapping Technique in Violin Training on the Cognitive, Psychomotor Skills and Attitudes of the Students, Education and Science. Vol. 43, No. 194, 285-310, 2018.

[52] Ismail, M. N., Ngah, N. A., \& Umar, I. N. The effects of mind mapping with cooperative learning on programming performance, problem solving skill and metacognitive knowledge among computer science students. J, Educational Computing Research, Vol. 42, No. 1, 35-61. 2010.

[53] Flavell, J. H. Metacognition and Cognitive Monitoring, A New Area of Cognitive-Developmental Inquiry, American Psychologist, Vol. 34, No. 10, 906-911, 1979.

[54] Budd, J. W. Mind maps as classroom exercises, The Journal of Economic Education, Vo. 35, No. 1, 2004.

[55] Jones,B. D., Ruf, C., Snyder, D. J., Petrich, B., \& Koonce, J. The Effects of Mind Mapping Activities on Students' Motivation, International Journal for the Scholarship of Teaching and Learning. Vol. 6, No. 1, 1-21, 2012.

[56] Nur, S., Zubaidah, S., Mahanal, S., Rohman, F. ERCoRe Learning Model to Improve Creative-Thinking Skills of Preservice Biology Teachers, Journal for the Education of Gifted Young Scientists, Vol 8, No. 1, 2020.

[57] Davies, M. Concept mapping, mind mapping, and argument mapping: what are the differences and do they matter, University of Melboune Australia, (2010).

[58] Listiana, L., Susilo, H., Suwono, H., Suarsini, E. Contributions of Metacognitive Skills Toward Students' Cognitive Abilities of Biology Through the Implementation of Gittw (Group Investigation Combined with Think Talk Write) Srategy. Prosiding ICTTE, Vol. 1, No. 1, 411-418, 2016.

[59] Chikmiyah, C. \& Sugiarto, B. Relationship between metacognitive knowledge ans Student Learning Outcomes through Cooperative Learning Model Type Think Pair Share on Buffer Sollution Matter, Unesa Journal of chemical Education, Vol. 1, No.1, 55-61, 2012. 
[60] Çalişkan, M., \& Sünbül, A. L. The Effects of Learning Strategies Instruction on Metacognitive Knowledge, Using Metacognitive Skills and Academic Achievement (Primary Education Sixth Grade Turkish Course Sample), Kuram ve Uygulamada Eğitim Bilimleri Educational Sciences: Theory \& Practice, Vol. 11, No. 1, 148-153, 2011.

[61] Corebima, A.D. Biology Learning in Indonesia is not for Living. Proceeding Biology Education Conference UNS, Vol. 13, No. 1, 8-22, 2016.

[62] Supriyatin., Rahayu, S., Ristanto, R.H., Ichsan, I, Z. Improving HOTS in Biology Learning: A Supplement Book of Plant Growth and Development, Universal Journal of Educational Research, Vol. \&, No. 12, 2642-2646. 2019. 